\title{
Taxation and Pricing of Petroleum Products in Developing Countries: A Framework for Analysis with Application to Nigeria
}

Shahabuddin M. Hossain 


\title{
IMF Working Paper
}

\author{
African Department
}

\section{Taxation and Pricing of Petroleum Products in Developing Countries: A Framework for Analysis with Application to Nigeria}

\author{
Prepared by Shahabuddin M. Hossain ${ }^{1}$
}

Authorized for distribution by Robert Sharer

February 2003

\begin{abstract}
The views expressed in this Working Paper are those of the author(s) and do not necessarily represent those of the $\mathrm{MMF}$ or IMF policy. Working Papers describe research in progress by the author(s) and are published to elicit comments and to further debate.
\end{abstract}

Using the modern theory of public economics as the point of departure, this paper outlines a basic principle for setting taxes and/or prices of commodities based on two key criteria, efficiency and equity. The paper shows that for petroleum products, the basic principle needs modification in the presence of various externalities and market imperfections in a setting where the instruments to address the externalities and imperfections are limited. Drawing from theoretical and empirical literature, the paper provides an operational framework and then illustrates how, for a country like Nigeria, the relevant taxes/subsidies to correct the externalities and to address equity and revenue considerations can be measured with a view to setting prices of petroleum products. However, the paper refrains from making any specific suggestion for policy reform in Nigeria. The framework outlined in the paper can be applied to the analysis of petroleum product taxes and prices in other developing countries.

JEL Classification Numbers: $\mathrm{H} 5, \mathrm{H} 21, \mathrm{H} 22$

Keywords: petroleum product prices; taxes; subsidies; efficiency; equity; revenue; border prices; externalities; road user charge; price stabilization

Author's E-Mail Address: shossain@imf.org

\footnotetext{
${ }^{1}$ The author is grateful to David Coe, Pierre Dhonte, Menachem Katz, Arvind Subramanian, Emil Sunley, and participants in an African Department seminar for their useful suggestions and comments. The usual disclaimer applies.
} 


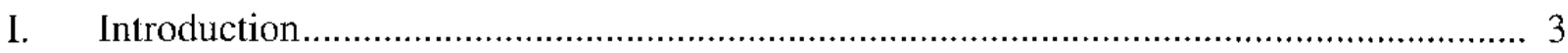

1I. Review of Literature: The Analytical Framework for Energy Pricing ........................... 5

A. Efficiency Price, Externalities, and Equity …........................................... 7

B. Externalities and Pricing: Road User Charges ............................................ 7

C. Externalities and Pricing: Environmental Taxes and Subsidies........................ 8

D. Instability in the Prices and Optimal Degree of Domestic Price Stabilization .. 9

E. Setting Prices of Petroleum Products: Different Components. ..........................10

III. Setting Prices of Petroleum Products in a Developing Country: A Case Study of Nigeria.....

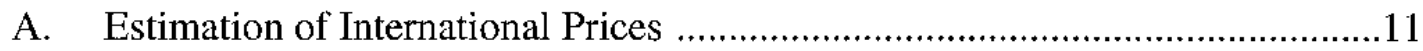

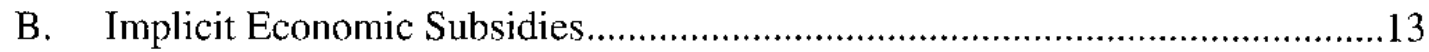

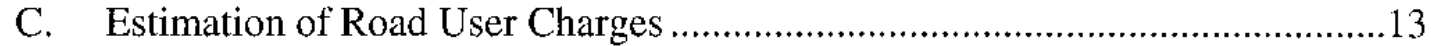

D. Estimation of Environmental Taxes and Subsidies........................................17

E. Estimation of the Benefits of Stable Domestic Prices....................................20

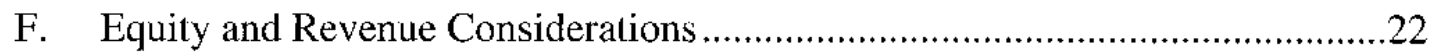

G. Results: Illustrative Final Prices of Petroleum Products.................................23

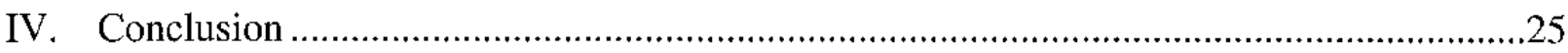

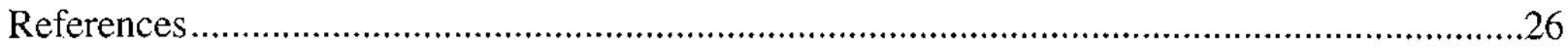

Tables

1. Pump Prices of Gasoline and Diesel in Selected Countries, 1998-2000 ...................... 4

2. Nigeria: Estimation of Import Parity Prices of Petroleum Products, 2002 ...................12

3. Nigeria: Petroleum Product Prices and Estimates of Economic Subsidy, 2002 ...............14

4. Nigeria: Estimation of Road User Charges, 1995-2002 .............................................16

5. Consumption Pattern of Kerosene and Firewood and Impact of Kerosene Subsidy..........18

6. Arbitrage and Risk Benefits of Partial Price Stabilization .........................................21

7. Nigeria: Illustrative Estimates of Prices of Petroleum Products, 2002 ..........................24 


\section{INTRODUCTION}

Domestic prices of petroleum products vary widely across countries. In many countries, including notably, industrial countries, prices are market determined and subject to only taxes and special levies. However, in other countries, notably developing countries, the prices are fixed by the government or state-owned enterprises. Table 1 shows the prices of gasoline and diesel in a number of countries around the world during 1998-2000. It indicates several striking patterns. First, the prices of gasoline and diesel varied widely across the countries. For instance, in Africa gasoline prices per liter in 2000 varied from as low as 20 cents in Ghana and 27 cents in Nigeria to about 86 cents in Uganda. Similarly, in OECD countries, the gasoline price per liter varied between 47 cents in the United States and 117 cents in the United Kingdom. Second, the level of gasoline and diesel prices is generally very low in oilexporting countries and high in developed market economies. Third, in general, the prices of gasoline are significantly higher than the prices of diesel fuel. These patterns and wide variation in prices of products reflect mainly wide variation in the levels of the taxes and subsidies on petroleum products imposed for various reasons.

The issue of domestic prices and taxation (subsidy) of petroleum products has important budgetary implications. For instance, domestic taxes on petroleum products provide a major source of revenue in developing countries, with their share of total revenue ranging from 7 percent to 30 percent in the early and mid 1990s (Gupta and Mahler, 1994). The revenue shares have been particularly high in some African countries, namely, Côte d'Ivoire, Kenya, Tanzania, and Uganda where the range was 10-30 percent. In a number of other countries, most notably oil-exporting countries, the prices are subsidized, implying that governments forgo a large amount of revenue as a consequence. For instance, net taxes on gasoline have varied from over 100 percent in a number of African countries to very low or even negative rates (implying net subsidies).

A key question, therefore is, what are the appropriate levels of taxation and prices of petroleum products? Or, put another way, what are the relevant factors that should be considered in setting the taxes on, and prices of, such products? It is an important policy issue that has implications, not only for microeconomic or allocative efficiency but also for the design of macroeconomic policies. In countries suffering from revenue shortfalls, increasing the taxes and prices of petroleum products is often recommended as a quick measure to boost revenue. In a number of countries, governments also subsidize some of the products as a tool for redistributing income toward the low-income segments of the population. To address the issue of appropriate taxes and prices, a systematic approach based on economic theory and principles is warranted. 
Table 1. Pump Prices of Gasoline and Diesel in Selected Countries, 1998-2000

(In U.S. cents per liter)

\begin{tabular}{|c|c|c|c|c|}
\hline \multirow[t]{2}{*}{ Country } & \multicolumn{2}{|c|}{ Gasoline Price } & \multicolumn{2}{|c|}{ Diesel Price } \\
\hline & 1998 & 2000 & 1998 & 2000 \\
\hline \multicolumn{5}{|l|}{ Africa } \\
\hline Angola 1/ & 38 & 30 & 19 & 15 \\
\hline Cameroon 1/ & 64 & 56 & 48 & 47 \\
\hline Côte d'Ivoire & 74 & 76 & 45 & 51 \\
\hline Ethiopia & 36 & 46 & 25 & 27 \\
\hline Ghana & 32 & 20 & 30 & 19 \\
\hline Kenya & 70 & 71 & 54 & 60 \\
\hline Mozambique & 55 & 56 & 41 & 54 \\
\hline Nigeria $1 /$ & 13 & 27 & 10 & 27 \\
\hline South Africa & 43 & 50 & 39 & 50 \\
\hline Tanzania & 63 & 75 & 57 & 73 \\
\hline Uganda & 86 & 86 & 68 & 75 \\
\hline Zambia & 53 & $\cdots$ & 49 & $\cdots$ \\
\hline Zimbabwe & 26 & 85 & 22 & 72 \\
\hline \multicolumn{5}{|l|}{ Asia } \\
\hline Bangladesh & 47 & 46 & 26 & 29 \\
\hline Hong Kong SAR & 136 & 146 & 85 & 80 \\
\hline India & 56 & 60 & 21 & 39 \\
\hline Indonesia 1/ & 16 & 17 & 7 & 6 \\
\hline Malaysia & 28 & 28 & 17 & 16 \\
\hline Pakistan & 46 & 53 & 19 & 27 \\
\hline Russia 1/ & 28 & 33 & 18 & 29 \\
\hline Saudi Arabia 1/ & 16 & 24 & 10 & 10 \\
\hline Singapore & 72 & 84 & 36 & 38 \\
\hline \multicolumn{5}{|l|}{ Latin America } \\
\hline Argentina & 94 & 107 & 42 & 52 \\
\hline Brazil & 80 & 92 & 34 & 34 \\
\hline Mexico 1/ & 36 & 61 & 28 & 45 \\
\hline Venezuela $1 /$ & 14 & 12 & 8 & 6 \\
\hline \multicolumn{5}{|l|}{ OECD Countries } \\
\hline Canada & 41 & 58 & 39 & 47 \\
\hline France & 111 & 99 & 77 & 82 \\
\hline Germany & 96 & 91 & 69 & 78 \\
\hline Italy & 119 & 97 & 93 & 83 \\
\hline Japan & 102 & 106 & 69 & 76 \\
\hline United Kingdom & 111 & 117 & 111 & 122 \\
\hline United States & 32 & 47 & 27 & 48 \\
\hline \multicolumn{5}{|l|}{ Memorandum item: } \\
\hline Global untaxed retail price & $\ldots$ & 32 & $\ldots$ & 30 \\
\hline
\end{tabular}

Source: Metschies (2001).

1/ Oil-exporting countries. 
The issue has been reviewed both at the theoretical and empirical level and in different contexts by a number of authors. Among others, Dixit and Newbery (1984) and Newbery (1985) discussed at length the theoretical principles guiding the taxation and prices of petroleum products in an economy where there are number of distortions and tax tools are limited. Empirically, Gupta and Mahler (1994) also discussed the principles of taxation and compiled information on taxation and pricing of petroleum products in a number of countries. More recently Gupta and others (2002) reviewed the issue of the domestic prices of petroleum products in oil-producing countries and quantified the implicit subsidies in those countries. They also discussed the economic effects of subsidies and taxes, including the efficiency, equity, and fiscal considerations. However, the papers do not provide an unified quantitative framework for setting the prices or taxes/subsidies in the context of a developing country, nor do they attempt to measure the ex ante appropriate level of taxes/subsidies, including those used to address externalities. Drawing from the theoretical and empirical literature, this paper proposes a simple but robust principle for setting taxes (subsidies) and/or prices of petroleum products, based on a number of key considerations, including efficiency, equity, and externality, in a setting where instruments to address equity and externalities are limited. The paper's main contribution lies in providing an operational framework to identify and estimate the components of prices, including taxes and subsidies to address externality, distribution, and revenue considerations; and in illustrating how, for a country like Nigeria, the components can be measured with a view to setting taxes and prices of petroleum products.

The paper is organized as follows. Section II discusses the appropriate analytical framework for energy pricing based on economic theory. Drawing from the relevant theoretical and empirical literature, it shows how the conventional pricing rule based on international (border) prices needs modification in the presence of various externalities and market imperfections in a setting where tax instruments to address the externalities are limited. Section III of the paper then proposes an operational framework and illustrates how, for a country like Nigeria, the relevant taxes/subsidies to address the externalities can be measured in order to set prices of petroleum products. It also shows how equity and revenue considerations can be incorporated into the framework. Section IV presents the findings of the study and the main conclusion. However, the paper refrains from making any specific suggestion for policy reform in Nigeria. The quantitative framework outlined in the paper has general applicability and can be readily used to analyze petroleum product taxes and prices in other developing countries.

\section{Review of Literature: The ANAlytical Framework for ENERgy Pricing}

The modern theory of public economics, as set out in the classic paper by Diamond and Mirrlees (1971), provides us with a very useful framework within which to analyze taxation and public pricing issues. It is postulated that under some assumptions public policies should be designed to achieve production efficiency, with all the distortionary taxes falling on final consumers. Two critical conditions are required for this result to hold: (a) production efficiency must be feasible, and (b) any resulting pure profits are either negligible or can be taxed fully. The feasibility condition would be met if competitive 
conditions prevailed in the economy and externalities could be corrected or internalized. ${ }^{2}$ The second would be met if it is assumed that government has unrestricted tax tools i.e. all goods can be taxed fully.

This general principle can be applied to the practical problem of setting the prices of major energy products in developing countries. We can start by making a conceptual distinction between producer (input) prices and consumer (final) prices. The producer prices are the prices facing producers, who use energy as inputs to production (e.g., farming, the transport sector and industry) and consumer prices are the prices consumers actually face in satisfying their final demand for energy (fuel or petrol for private transport, and gas, kerosene, or electricity for domestic use). The basic rule of public pricing could be stated as follows: set producer (input) prices at an efficient level and then choose the appropriate level of taxes or subsidies based on equity criterion to get the consumer (final) prices. As indicated earlier, this rule is valid in a competitive economy in which profits or rents are either negligible or adequately taxed, and government has fiscal policy instruments available to separate consumer and producer prices and to correct for externalities, if necessary (Newbery, 1985).

\section{However, a number of features of developing countries, as well as some additional} considerations, make it difficult and often undesirable to implement the basic rule indiscriminately. In developing countries, many sources and types of externalities cannot be corrected easily because of restrictions on the tax tools or other instruments available to the government. Because of administrative and informational constraints, government often does not have the tax instrument (e.g., value-added tax (VAT)) necessary to separate consumer and producer prices effectively. The role of direct taxes (e.g., income tax) or transfers as a distributive mechanism is also very limited in many developing countries, with the result that equity considerations are of considerable importance in the design of indirect taxes in general, and energy taxes in particular. This makes it difficult to separate equity and efficiency criteria, noted above. Even if it is possible to separate the producer and consumer prices of particular energy products, the existence of taxes on other inputs to production, and pervasive distortions and externalities elsewhere in the economy that can not be addressed directly, makes it difficult to compute the appropriate prices for the producers. ${ }^{3}$

\footnotetext{
${ }^{2}$ Implicitly, production efficiency is often argued to require a complete set of futures and insurance market, and no restriction on taxation of goods.

${ }^{3}$ Dixit and Newbery (1984) discuss two policy options to correct the distortions (e.g., restricted trade and exchange rate policy). One is to carry out a major policy reform (e.g., liberalizing tariffs, quotas, and exchange rate regime) with a view to removing the primary sources of distortion. The other, often more realistic altemative is to have a duty drawback scheme whereby the producer can recoup the duty on the imported inputs. Only if these policy options are not feasible and there are inefficiencies that cannot be corrected at the source, should the government adopt a second-best approach of setting energy prices in such a way as to offset the inefficiencies/distortions elsewhere in the economy.
} 


\section{A. Efficiency Price, Externalities, and Equity}

In many developing countries, the public authorities can control the prices of petroleum products, either directly through the monopoly position of public sector agencies as sole supplier of these products, or indirectly through commodity taxes, subsidies and pricing regulations. Assuming that the public authorities can always choose the appropriate level of taxes and tariffs for non-energy inputs, the theory of public economics suggests that input prices for energy should be set equal to the efficient prices. If there are no trading constraints in the international market, the efficient price for a fully traded good would be the international or border price (import or export parity price), suitably adjusted for quality differences and the domestic transport and distribution margins. ${ }^{4}$ The rule is applicable to all traded goods, including petroleum products.

As noted above, the simple rule of setting prices at the level of international prices requires modification in the presence of externalities that can not be corrected at the source; moreover, equity considerations affect taxation and pricing policy when the government faces restrictions on the use of redistributive tools (income taxes or transfers). However, modifying the pricing rule is not straightforward for a number of reasons. First, it is difficult to identify and measure externalities, all the more so because using a specific fuel for different economic activities may mean that the appropriate price for the same fuel may differ depending on the uses. For instance, diesel is used as fuel in many different activities, including road transport, tractor farming, electricity generation, and heating machines. Second, as certain kinds of energy products, such as kerosene and coal, are traded domestically, it is not possible to separate the consumer and input prices, so that income distributional considerations could also enter in setting the prices of these products. It appears that the petroleum products that fall into these problem categories are diesel (used as an input and final consumption product) and kerosene (consumed predominantly by the poor and as a close substitute for firewood). ${ }^{5}$ We begin by examining the externalities that are relevant to taxation and pricing policy.

\section{B. Externalities and Pricing: Road User Charges}

Externalities may arise in a wide variety of situations, some of which cannot be corrected at the source through the policy instruments available to the government. For example, vehicles using roads and motorways impose social costs on the society beyond the private costs that the users themselves bear. These social costs include accidents, environmental pollution, road damage, and congestion (Newbery, 1988). Ideally, the government should be able to charge road users an amount equal to the social costs they impose on the rest of the society. Direct policy instruments, such as electronic metering in

\footnotetext{
${ }^{4}$ Import parity price is applicable if the country is a net importer of the products, and export parity price is applicable if the country is a net exporter.

${ }^{5}$ Gasoline is used predominantly as a fuel for motor vehicles, but it may also cause a problem if it is used extensively as an input to other activities.
} 
Hong Kong SAR, have been devised to tackle this externality, but their use is severely impractical in developing countries, as is the equally impractical and inconvenient method of collecting tolls from the road users. At the same time, levying fixed vehicle license fees cannot generate revenue equal to the social costs imposed because it cannot charge the road users in proportion to road use.

Alternative instruments are therefore needed to deal with the road damage externality. A natural choice is to charge road users for the social costs they impose through the transport fuel tax. This tax has the attractive feature of charging road users in proportion to road use, and, when combined with an annual license fee, it can discriminate between types of vehicles with differing road damaging capability (heavy trucks and vehicles can cause many times more damage than cars or light vehicles). ${ }^{6}$ Thus a combination of vehicle-specific (e.g., license fees, and purchaser taxes) and distance-related charges (taxes on fuel and tires) can be used to make road users pay for the externalities they cause. ${ }^{7}$ Among others, World Bank (1988) provides a methodology, elaborated in Section III, for estimation of road user charges to be levied on transportation fuels in developing countries.

In summary, even though the principle of public economics suggests that there should be no taxation of intermediate inputs and all taxes should fall on final consumers, the presence of externalities and the lack of policy instruments to correct the externalities at the source call for the modification of the principle in particular cases.

\section{Externalities and Pricing: Environmental Taxes and Subsidies}

In addition to the above-mentioned case, many forms of externality cannot be corrected at their source, and thus require taxation or subsidization of complementary or substitute products. In the context of energy products, another important case relates to the desirability of subsidizing the use of kerosene in developing countries. There appear to be two different arguments for the subsidy. First, a subsidy on kerosene is likely to reduce deforestation externalities resulting from excessive consumption of wood as fuel in developing countries. Second, social equity requires the subsidization of basic needs such as kerosene, which is used by both urban and rural low-income groups that cannot be reached easily by alternative government programs.

The first argument is particularly interesting. In many densely populated countries, the destruction of forests to meet firewood requirements has reached an alarming level. Deforestation is said to impose severe social costs on society: it not only degrades the local

${ }^{6}$ Technology (e.g. electronic censors) also exists to charge vehicles according to weights and distance traveled. However, administrative difficulties and cost prevent its widespread use.

${ }^{7}$ In many countries, both developed and developing, Road Funds have been set up to help maintain and construct new roads with revenues derived largely from taxes on fuels. In the United States, a large part of the taxes on petrol and fuel go into the Federal Highway Trust Fund, which is used to maintain and construct new roads and highways. 
and national environment but also causes soil erosion resulting in floods; in some situations, it also causes or intensifies the desertification process. Even though the full social cost of desertification cannot be quantified, its impact is certainly perceptible to members of the society. Deforestation gives rise to externality because the private users of the forest, in trying to meet their firewood, timber, raw material, or other demands, do not pay for the social cost they impose on the rest of the society by degrading the environment. This problem is very difficult to tackle directly because of the nonmarket nature of wood gathering in rural areas and the common property nature of a large part of the forest resources in developing countries. Government regulations aiming at curbing the depletion of forest resources have not been very effective in combating the problem. It is thus argued that, to the extent that kerosene acts as a substitute for firewood and lower prices for kerosene lead to a reduction in firewood use, kerosene should be subsidized to encourage substitution between fuels. Among others, Hughes (1983) reviewed the possible impact of such subsidies in the context of Thailand, an issue examined empirically in Section III.

\section{Instability in the Prices and Optimal Degree of Domestic Price Stabilization}

A case can also be made for using variable taxes/subsidies as instruments to stabilize domestic prices of petroleum products in the face of volatility in international prices. As there is a great deal of volatility in the international price of oil and petroleum products, the adoption of an international price rule will also introduce price instability into the domestic market. Since most producers and consumers are by nature risk averse, these frequent price changes impose some costs to them. If there is a full set of insurance markets and economic agents have access to credit and facilities to hedge risks fully, there is no need for intervention in the market to achieve price stability. However, in many developing countries, insurance markets are limited, and consumers and producers often lack access to credit and other facilities to hedge risks. In such circumstances, there may be a case for insulating the domestic prices (at least partially) from the volatility of world prices; this could be done either by imposing variable taxes and/or subsidies or by other means. ${ }^{8}$ However, the benefits of price stabilization must be sufficiently high to justify such taxes/subsidies. Newbery and Stiglitz (1981, pp. 93-99) developed a rigorous framework to measure such benefits. In a situation of limited data, Newbery (1990), suggested summary measures for empirical estimation of the possible benefits of domestic "price stabilization," making use of the modified measure of "arbitrage benefit" (based on the Marshallian surplus measure) and "risk benefit." These measures are defined as follows:

$$
\begin{aligned}
& (B / X)_{A}=(1 / 2) \cdot \varepsilon \cdot\left(1-\alpha^{2}\right) \cdot \alpha_{p}^{2} \quad \text { (arbitrage benefit) } \\
& (B / X)_{R}=(1 / 2) \cdot R \cdot\left(1-\alpha^{2}\right) \cdot \alpha_{p}^{2}, \quad \text { (risk benefit) }
\end{aligned}
$$

\footnotetext{
${ }^{8}$ Newbery and Stiglitz (1981) examined the issue in great detail in a somewhat different context. Given the volatility of the prices of primary commodities, they examined the desirability and feasibility of international price stabilization schemes. However, their theoretical work and empirical estimates do not support the case for international price stabilization.
} 
where, $(B / X)=$ benefit as a percent of total expenditure on the commodity;

$\varepsilon=$ elasticity of demand (a constant elasticity demand curve is assumed);

$R=$ coefficient of relative risk aversion;

$\alpha=$ fractional reduction in $\alpha_{\mathrm{p}}^{2}$ due to stabilization measure; and

$\alpha_{p}^{2}=$ coefficient of variation in initial prices.

As will be seen below, empirical estimates of these measures provide a basis for judging the desirability and feasibility of a domestic price stabilization scheme.

\section{E. Setting Prices of Petroleum Products: Different Components}

Based on the discussion so far, it is possible to identify at least six components that should be considered while setting price of a petroleum products:

where

$$
p=p^{*}+t_{1}+t_{2}+t_{3}+t_{4}+t_{5}
$$

$p^{*}=$ international (border) prices,

$t_{1}=$ road user charges (to address road damage externality),

$t_{2}=\quad \operatorname{tax} /$ subsidy to address environmental externality,

$t_{3}=\quad \operatorname{tax} /$ subsidy set to reduce variability in price,

$t_{4}=$ tax/subsidy set for distributional (equity) considerations, and

$t_{5}=\operatorname{tax}$ for revenue considerations.

Tax authorities impose taxes $\left(t_{5}\right)$ on final consumption purely to raise revenue based on revenue requirements. It could take the form of VAT or other taxes. Taxation of petroleum products for revenue reasons should be based on same general tax principles as in the case of other taxation of other commodities. A traditional guide to raising revenue has been the Ramsey tax rule, which suggests that commodities that are relatively insensitive to changes in price (low price elasticity of demand) should be taxed more than commodities that are sensitive to changes in price (high price elasticity of demand) ${ }^{9}$ However, the Ramsey tax rule is rather inegalitarian in that it appears to direct commodity taxation toward "necessities" that are fairly insensitive to price. Where income distributional or equity considerations are important and authorities have limited income tax and transfer systems to address distributional concerns, the rule needs to be modified. In general, to raise revenue, the imposition of a VAT (or general sales tax) or a general increase in VAT rates is preferable to

\footnotetext{
${ }^{9} \mathrm{~A}$ more rigorous formulation of the Ramsey or optimal commodity tax rule is the following: commodity tax rates should be such that proportional reduction in "compensated demand" (that results from the taxes) should be equalized across goods, which generally implies nonuniformity in tax rates. This rule presupposes complete information relating to own- and cross-price elasticities for all goods and unlimited tax powers of government, neither of which are achievable in practice.
} 
arbitrary taxes on individual commodities. A VAT is a nondiscriminatory and neutral tax that avoids distortion associated with taxation of inputs to production. ${ }^{10}$

Section III provides empirical estimates of these components of energy prices for Nigeria, illustrating how the simple efficiency (international) pricing rule should be modified to take systematic account of externalities, market imperfections, and equity and revenue considerations in the context of a developing country with limited tools to address externality, imperfections, and equity increases.

\section{Setting Prices of Petroleum Products in a Developing Country: A Case STUDY OF NIGERIA}

\section{A. Estimation of International Prices}

Nigeria produces crude oil commercially, and it has three functioning refineries that use domestically produced crude oil. It also imports and exports some petroleum products because the product composition of the refinery output does not exactly match the composition of domestic demand. Consumption data clearly indicate that the middle distillates, like gasoline and diesel, dominate the demand structure; the country is often a net importer of these products. In the past, the very low regulated price of petroleum products, combined with the low level of capacity utilization of the refineries (reflecting poor maintenance and mismanagement) gave rise to cross-border smuggling of petroleum products. Domestic production levels periodically fell short of total demand, leading to shortages of products and, as a result, to high levels of gasoline and diesel imports.

\section{In general, the international (border) price of a commodity represents its opportunity} cost in the country if the products are fully traded in international market as in the case of petroleum products. For the major products-gasoline, diesel and kerosene - the derivation of the border prices is a relatively straightforward task, as the prices are quoted on a daily basis in the international market with standard quality specification. The estimates of average border prices of all these products in 2002 are presented in Table 2. The c.i.f. prices refer to the monthly average price quoted in Rotterdam or Mediterranean (Italy), the nearest source of supply for Nigeria. The exchange rate used to convert the dollar value of imports into domestic currency is the interbank exchange market rate, which is market determined. As indicated in the table, a freight charge (including insurance margin) is added to the value to get the landed cost. Import duty, domestic distribution, storage, marketing, and transport margins are then added to obtain the border price at the retail level.

${ }^{10}$ Hossain (1995) provides a framework to measure the equity impact of VAT and demonstrates how equity concerns can be incorporated in the design of a system of taxation, including VAT. 
Table 2. Nigeria: Estimation of Import Parity Prices of Petroleum Products, 2002

(Naira per liter, unless otherwise indicated)

\begin{tabular}{|c|c|c|c|}
\hline & $\begin{array}{r}\text { Gasoline } \\
\text { (Petrol) }\end{array}$ & Diesel & Kerosene \\
\hline \multicolumn{4}{|l|}{ Structure of prices } \\
\hline Retail price: $1995-1998$ & 11.0 & 9.0 & 6.0 \\
\hline Retail price: 1999 & 20.0 & 19.0 & 17.0 \\
\hline Retail price: $2000-2001$ & 22.0 & 21.0 & 17.0 \\
\hline Retail price (after increase in January 2002) $1 /$ & 26.0 & 26.0 & 24.0 \\
\hline \multicolumn{4}{|l|}{ Estimation of international prices } \\
\hline Product price: f.o.b. (U.S. dollar per metric ton) $2 /$ & 249.0 & 220.4 & 230.7 \\
\hline Product conversion factor (liter per metric ton) & $1,350.0$ & $1,150.0$ & $1,235.0$ \\
\hline Product price (U.S. cents per liter) & 18.4 & 19.2 & 18.7 \\
\hline Interbank exchange rate (naira per U.S. dollar) $3 /$ & 124.0 & 124.0 & 124.0 \\
\hline Product price: f.o.b. (naira per liter) $[\mathrm{A}]$ & 22.9 & 23.8 & 23.2 \\
\hline Freight to West Africa (U.S. dollar per metric ton) 4 / & 25.0 & 25.0 & 25.0 \\
\hline Freight (U.S. cents per liter) & 1.9 & 2.2 & 2.0 \\
\hline Freight (naira per liter) $[\mathrm{B}]$ & 2.3 & 2.7 & 2.5 \\
\hline Landed cost (naira per liter) $[\mathrm{A}+\mathrm{B}]$ & 25.2 & 26.5 & 25.7 \\
\hline Customs/import duty & 1.5 & 1.5 & 1.5 \\
\hline Distribution and storage margins $5 /$ & 2.0 & 2.0 & 2.0 \\
\hline Marketing and dealers' margin $5 /$ & 5.4 & 5.4 & 5.4 \\
\hline Retail import/border price (before domestic taxes) & 34.1 & 35.4 & 34.6 \\
\hline \multicolumn{4}{|l|}{ Memorandum items: } \\
\hline Current (2002) price in percent of import/border price & 76.3 & 73.5 & 69.4 \\
\hline Import/border prices in percent of current (2002) retail price & 23.7 & 26.5 & 30.6 \\
\hline
\end{tabular}

Sources: Nigerian National Petroleum Corporation (NNPC), Yearly Reports; Platt's Oilgram Price Reports ;

and author's estimates.

1/ Retail prices of petroleum products after adjustments in January 2002.

2/ Data on product prices and freight (U.S. dollar per metric ton) for 2002 are obtained from Platt's Oilgram Price Reports

(Rotterdam or Mediterranean); average monthly product prices (excluding few months with extreme values).

3/ Average exchange rate prevailing in the interbank foreign exchange market in mid-(July) 2002.

4/ Average cost of bulk cargoes from Europe; includes cost of insurance.

5/ Reflects industry norms; includes port charges. In practice, margins for kerosene are somewhat lower. 


\section{B. Implicit Economic Subsidies}

Table 3 presents estimates of economic subsidies on petroleum products. It shows that (a) the current prices of petroleum products in Nigeria are still much below their international prices, implying that they are heavily subsidized; and (b) the magnitude of subsidy is very large. Compared with the international or border price of N35.2 per liter, the current domestic price of gasoline (petrol) is only N26 per liter, implying a subsidy of 26.2 percent relative to the international price. Given the retail prices of two other major fuels, diesel and kerosene (N26 per liter and N24 per liter, respectively), their implicit economic subsidies are estimated at 26.5 percent for diesel and 30.6 percent for kerosene. Estimates based on volume data indicate that, measured at international/border prices, the total economic subsidy to the users of petroleum products is N94 billion, or about 1.8 percent of GDP, in 2002, about two-thirds of which is due to the subsidy on gasoline. ${ }^{11}$ It appears that the pricing policy pursued by the Nigerian authorities, has large fiscal and economic costs. ${ }^{12}$ The measure of international/ border prices, however, does not include any domestic tax or subsidy to address externality, equity, or domestic revenue considerations. As noted above, there is a strong case for imposing a tax/subsidy for road damage, congestion, and environmental externalities (e.g., road user charges) when tools are not available to correct such externalities at the source. ${ }^{13}$ The road user charges for petrol and diesel are computed in the following section based on a simplified methodology.

\section{Estimation of Road User Charges}

Gasoline and diesel are used predominantly as transport fuels. However, diesel is also used as major input in agriculture, industry, and power generation. For simplicity, we have assumed that petrol is used entirely as a transport fuel and 50 percent of the diesel is used as transport fuel, with the rest serving as an industrial input (e.g., to generate power). The computation of road user charges has two components: (a) road damage costs and (b) congestion costs. Road damage costs vary greatly across types of vehicles, trucks, and buses, with high-axle loads

II The subsidy ( $\operatorname{tax}$ ) estimates shown in Table 3 are not necessarily budgetary subsidies (taxes) that the government imposes; rather, they represent the economic subsidies (taxes) measured by comparing the current prices with the international prices, reflecting opportunity costs of the products.

${ }^{12}$ Since the retail prices of products were substantially lower prior to the adjustment of product prices in early 2002 (Table 2), the cost of subsidies was substantially higher in the past.

${ }^{13}$ If an element of road user charges is added to the border prices of petrol and diesel, the two main fuels used in transport, their shadow prices (opportunity costs) would increase as would the subsidy element relative to the shadow price. However, if the price of kerosene were to include a corrective element (subsidy) to address the deforestation externality, its shadow price would go down. 
Table 3. Nigeria: Petroleum Product Prices and Estimates of Economic Subsidy, 2002

\begin{tabular}{|c|c|c|c|}
\hline Products & $\begin{array}{l}\text { Gasoline } \\
\text { (Petrol) }\end{array}$ & Diesel & Kerosene \\
\hline Retail price (naira per liter) & 26.0 & 26.0 & 24.0 \\
\hline Retail import/border price (naira per liter) $1 /$ & 35.2 & 35.4 & 34.6 \\
\hline Rate of economic subsidy (in percent of import/border price) & 26.2 & 26.5 & 30.6 \\
\hline Import/border prices in percent of retail price & 135.5 & 136.0 & 144.0 \\
\hline Volume of sales (in millions of liters) $2 /$ & $9,127.5$ & $2,648.2$ & $1,642.0$ \\
\hline Value of sales at current price (in billions of naira) & 237.3 & 68.9 & 39.4 \\
\hline Volume of saie at import/border price (in millions of liters) $3 /$ & $8,480.1$ & $2,457.5$ & $1,569.7$ \\
\hline Value of sales at international prices (in billions of naira) & 298.7 & 86.9 & 54.3 \\
\hline Economic subsidy (in billions of naira) & 61.4 & 18.0 & 14.9 \\
\hline \multicolumn{4}{|l|}{ Memorandum item: } \\
\hline Economic subsidy in percent of GDP & 1.2 & 0.3 & 0.3 \\
\hline
\end{tabular}

Sources: Nigerian National Petroleum Corporation (NNPC), "Report on Operations, January-June, 2002;" and author's estimates.

1/ Import/border prices are measured at interbank exchange rate (Table 2).

2/ Based on six months' sales data reported by Nigerian National Petroleum Corporation (NNPC).

3 / It is assumed that the price elasticity of demand is very low: for gasoline and diesel it is $\mathbf{0 . 2}$ and for kerosene it is -0.1 .

The demand response to an increase in price would be negative; however, if increase in prices lead to an improvement in supply by eliminating shortages, demand may go up (if prices are deregulated), thereby partly offsetting the negative impact of the price increase. 
causing more damage to roads than motor cars and other lighter forms of transport. It is, therefore, inappropriate to distribute the burden of road user charges uniformly across vehicles. Accordingly, as discussed above, a system of road user charges designed to recover road damage costs should consist of both a general tax on road transport fuel and vehiclespecific taxes, such as import, excise, and sales taxes. Heavy vehicles like trucks and buses should face higher import and excise taxes than lighter forms of transport. Congestion costs, the second component of road user charges, depend partly on the type of transport system, and studies indicate that these costs are (a) less important than road damage costs on unpaved roads, (b) comparable to road damage costs on paved intercity roads, and (c) more important on paved urban roads.

Theoretical and empirical work on road deterioration and maintenance has shown that it is possible to specify robust rules for calculating road damage costs (World Bank, 1988), as noted below. Table 4 presents the basic available data and shows how road user charges are computed from that data. The data for computing road damage costs and congestion costs come from a World Bank (1996) study. The total road length in Nigeria was approximately 190,000 kilometers, of which only about 22 percent, or about 42,000 kilometers, was paved and assumed to be subject to road damage externality. Although actual expenditure on highways and the road network in recent years has been somewhat higher than the budgeted expenditure, the amount spent has been much lower than what has been required for routine maintenance and rehabilitation of the road network. Actual expenditure for 1994-95 was computed by the World Bank in its 1996 public expenditure review. For 1998 and the most recent year, 2002, we extrapolated the estimates by keeping the value constant in real terms and adding the net yearly depreciation costs to the estimate, thus covering fully routine maintenance of the road network. Based on the methodology suggested by the World Bank (1988), the road user charge is then computed according to the following five-step procedure (Table 4):

- Sum all pavement and bridge-related annual expenditures, including rehabilitation, resurfacing, and routine maintenance items, but excluding construction items related to the extension of the network and routine nonpavement maintenance. The estimate is N54.6 billion in 2002 (final column in Table 4).

- Make the standard assumption that the proportion of road damage attributable to environmental damage under wet nonfreezing conditions is only 30 percent; this implies that road damage costs attributable to traffic loading are 70 percent (N38.2 billion in 2002).

- Compute the unit road damage cost by distributing the amount uniformly across the volume of gasoline and diesel used as road transport fuel. The unit road damage costs estimated following this methodology amount to N3.9 per liter in 2002.

- Compute congestion costs as follows: the congestion unit cost is two-thirds of the sum of (a) the adjusted total road damage costs estimated above (proxy for the quality of road use) and (b) the interest on the capital value of the road network, e.g., the real 
Table 4. Nigeria: Estimation of Road User Charges, 1995-2002

(in biltions of naira, unless otherwise specified)

\begin{tabular}{|c|c|c|c|}
\hline & $\begin{array}{c}1995 \\
\text { Est. 1/ }\end{array}$ & $\begin{array}{c}1998 \\
\text { Est. 2/ }\end{array}$ & $\begin{array}{c}2002 \\
\text { Est.. 2/ }\end{array}$ \\
\hline Recommended annual requirement (expenditure on roads) & 13.8 & 28.3 & 62.9 \\
\hline Recurrent & 2.7 & 5.6 & 12.4 \\
\hline Capital & 11.1 & 22.7 & 50.5 \\
\hline Rehabilitation, resurfacing, and repairs & 9.3 & 18.9 & 42.2 \\
\hline New projects: extension of the network & 1.8 & 3.8 & 8.4 \\
\hline \multicolumn{4}{|l|}{ Road damage externality } \\
\hline Cost of rehabilitation, resurfacing, and repairs & 12.0 & 24.5 & 54.6 \\
\hline \multicolumn{4}{|l|}{ Proportion of damage attributable to weather } \\
\hline under wet, nonfreezing condition (in percent) & 30.0 & 30.0 & 30.0 \\
\hline Road damage (cost) attributable to traffic loading $(D I) 3 /$ & 8.4 & 17.2 & 38.2 \\
\hline \multicolumn{4}{|l|}{ Fuel consumption (millions of liters) } \\
\hline Gasoline (petrol) & 5.6 & 4.8 & 8.5 \\
\hline Diesel & 2.6 & 2.1 & 2.5 \\
\hline Proportion of petrol used in road transport (in percent) & 100.0 & 100.0 & 100.0 \\
\hline Proportion of diesel used in road transport (in percent) & 50.0 & 50.0 & 50.0 \\
\hline Gasoline used in road transport $(X)$ & 5.6 & 4.8 & 8.5 \\
\hline Diesel used in road transport $(Y)$ & 1.3 & 1.0 & 1.2 \\
\hline 1. Unit road damage cost (naira per liter): $[D I /(X+Y)]$ & 1.2 & 3.0 & 3.9 \\
\hline \multicolumn{4}{|l|}{ Congestion costs } \\
\hline Road damage (cost) attributable to traffic loading $(D I)$ & 8.4 & 17.2 & 38.2 \\
\hline Length of the paved road network (thousands of kilometers) & 41.8 & 41.8 & 41.8 \\
\hline Unit capital value of the network (mill. naira per kitometer) & 40.0 & 61.4 & 93.5 \\
\hline Capital value of the network & $1,672.0$ & $2,568.6$ & $3,907,5$ \\
\hline Rate of depreciation (in percent) & 20.0 & 20.0 & 20.0 \\
\hline Cost of replacement investment & 334.4 & 513.7 & 781.5 \\
\hline Interest/discount rate (in percent) & 10.0 & 10.0 & 10.0 \\
\hline Interest on the capital value of the network (D2) $4 /$ & 33.4 & 51.4 & 78.1 \\
\hline Total: $(D l+D 2)$ & 41.8 & 68.5 & 116.3 \\
\hline Total congestion cost: two-third of $(D 1+D 2)=D 3$ & 27.9 & 45.7 & 77.6 \\
\hline II. Congestion unit cost (naira per liter): $[(D 3) /(X+Y)]$ & 4.1 & 7.9 & 8.0 \\
\hline Road user cost/charge (naira per liter): I + II $5 /$ & 5.3 & 10.8 & 11.9 \\
\hline
\end{tabular}

Sources: World Bank (1996); and author's estimates.

1/ Estimates based on 1994-95 data.

2/ Estimates based on 1995 estimates, inflation (non-oil GDP deflator) and assumed net yearly depreciation cost

of about 10 percent.

3/ The road damage attributable to traffic loading is assumed to be 70 percent of total..

4/ Equals the real international opportunity cost of borrowing on the replacement cost of the network.

5/ The road user cost must be added to the international (border) prices to derive the target retail pricc. 
opportunity costs of borrowing on the replacement cost of the network. ${ }^{14}$ The estimate for 2002 is N77.6 billion, resulting in a unit congestion cost of N8 per liter.

- The road user charge is then equivalent to the sum of the road damage unit costs and the congestion unit cost. For Nigeria, the estimate for 2002 is 11.9 per liter. In this exercise, however, the vehicle-specific costs required to cover a part of the road damage externality were not measured.

The implication for taxation and public pricing policy is that road user charges should be added to the border prices $\left(p^{*}\right)$ of gasoline and diesel, in the form of taxes $\left(t_{2}\right)$, to recoup a substantial part of the costs of road damage and congestion externalities. As noted above, such taxes are commonplace in many countries, including the United States. The taxes may be imposed as distinct road user charges or subsumed in other taxes (e.g., excise taxes). The levels also differ widely across countries, depending on how much of the road damage and congestion externality the government would like to recoup and the availability of other methods of charging road users, namely, toll collection on highways (and on bridges and in tunnels), vehicle-specific taxes, and taxes on tires and other vehicle parts.

\section{Estimation of Environmental Taxes and Subsidies}

An attempt has been made to examine the possible impact of the kerosene subsidy on the use of firewood and its effectiveness in addressing the deforestation externality. Since the complete set of data required to measure the externality and calculate corrective taxes or subsidies are not available for Nigeria, we have complemented the available data with relevant data from another developing country for the illustrative exercise presented in Table 5. Panel A of Table 5, based on Nigerian household expenditure data, indicates that, while fuel and lighting expenditure make up about 6 percent of household expenditure in both urban and rural areas, the kerosene (used for cooking and lighting) alone takes up the bulk of this expenditure--2.4 percent of total expenditure in urban areas and 1.9 percent in rural areas. Firewood, however makeup only about 1.2 percent of total expenditure in urban areas but 3.2 percent of expenditure in rural areas. Survey data also show that, while, on the one hand, a large proportion (about 52 percent) of the urban population uses kerosene, only about 28 percent of rural population does so. On the other hand, an overwhelmingly large share of the rural population ( 80 percent) uses firewood, while only 44 percent of urban households use the fuel.

Panel B of Table 5 shows estimates of expenditure and price elasticities (own and cross) for kerosene and firewood for Bangladesh. In the absence of Nigerian data, such estimates for

\footnotetext{
${ }^{14}$ The methodology is based on empirical studies of congestion costs, including those conducted by the World Bank.
} 
Table 5. Consumption Pattern of Kerosene and Firewood and Impact of Kerosene Subsidy

A. Consumption Pattem of Firewood and Kerosene (In percent)

\begin{tabular}{lcc}
\hline & Urban & Rural \\
\hline Fuel and lighting: expenditure share & 6.1 & 6.3 \\
Kerosene: expenditure share & 2.4 & 1.9 \\
Firewood: expenditure share & 1.2 & 3.2 \\
percent of households using kerosene & 52.0 & 28.0 \\
Percent of households using firewood & & 84.0 \\
\hline
\end{tabular}

Source: Estimates based on household expenditure survey data of Nigeria (1992-93).

B. Elasticity Estimates: Expenditure, Own- and Cross-Price Elasticity of Demand 1/

\begin{tabular}{|c|c|c|c|}
\hline \multirow[b]{2}{*}{ Demand Elasticity } & \multicolumn{3}{|c|}{ With Respect To } \\
\hline & Expenditure & $\begin{array}{l}\text { Price of } \\
\text { kerosene }\end{array}$ & $\begin{array}{l}\text { Price of } \\
\text { firewood }\end{array}$ \\
\hline Kerosene & $\begin{array}{c}0.533 \\
(12.62)\end{array}$ & $\begin{array}{r}-0.109 \\
(-2.0)\end{array}$ & $\begin{array}{r}0.015 * \\
(0.69)\end{array}$ \\
\hline Firewood & $\begin{array}{c}0.657 \\
(14.30)\end{array}$ & $\begin{array}{l}0.857 \\
(7.75)\end{array}$ & $\begin{array}{c}-1.354 \\
(-42.92)\end{array}$ \\
\hline
\end{tabular}

Source: Hossain (1991).

1/ Estimates based on Bangladesh data.

* Statistically insignificant al 95 percent confidence level; figures in the parentheses indicate $t$ valucs.

C. Impact of a Kerosene Price Subsidy Scheme (Relative to Border Price)

\begin{tabular}{|c|c|c|c|}
\hline & $\begin{array}{r}10 \text { percent } \\
\text { subsidy }\end{array}$ & $\begin{array}{r}20 \text { percent } \\
\text { subsidy } \\
\end{array}$ & $\begin{array}{r}30 \text { percent } \\
\text { subsidy }\end{array}$ \\
\hline Border (reference) price of kerosene (naira per liter) & 34.6 & 34.6 & 34.6 \\
\hline Subsidized price of kerosene (naira per liter) & 31.1 & 27.7 & 24.2 \\
\hline Gain in urban income/expenditure (in percent) $1 /$ & 0.2 & 0.5 & 0.7 \\
\hline Gain in rural income/expenditure (in percent) $1 /$ & 0.2 & 0.4 & 0.6 \\
\hline Increase in demand for kerosene (in percent) $2 /$ & 1.1 & 2.2 & 3.3 \\
\hline Decline in demand for fircwood (in percent) $3 /$ & -8.6 & -17.1 & -25.7 \\
\hline \multicolumn{4}{|l|}{ Cost of subsidy or forgone revenue } \\
\hline (in percent of GDP) & 0.1 & 0.2 & 0.3 \\
\hline
\end{tabular}

Sources: Nigerian Household Expenditure Survey data; and author's estimates.

1/ The gain in urban/rural income (expenditure) is assumed to be directly proportional to the expenditure share of kerosene in the consumption basket.

2/ Demand for kerosene is expected to increase in proportion to its own-price elasticity as a result of subsidy-induced decline in kerosene price.

3/ Demand for firewood is expected to decline in proportion to its cross-price elasticity (with respect to kerosene price) as a rcsult of subsidy-induced decline in kerosene price. 
Bangladesh are used for illustrative purposes. ${ }^{15}$ The table shows that (a) expenditure elasticities of both kerosene and firewood are positive and highly significant but less than unity; (b) own price elasticities of demand for kerosene and firewood are both negative and significant; (in absolute terms the elasticity is less than one for kerosene but greater than one in case of firewood, and (c) most important, the elasticity of demand of firewood with respect to kerosene price is positive (close to one) and highly significant. ${ }^{16}$ This tends to suggest that kerosene is a substitute for firewood, and a rise and fall in the kerosene price has an appreciable impact on the demand for firewood.

Panel C of Table 5 shows the illustrative impact of kerosene price subsidies of 10 percent, 20 percent, and 30 percent, all measured relative to the border price of kerosene. As noted above, a subsidy in kerosene will have two distinct impacts: a reduction in price will lead to a gain in income in urban and rural areas in proportion to its expenditure shares; and it will lead to fuel substitution, i.e., an increase in the demand for kerosene and a decrease in the demand for firewood. The illustrative estimates indicate that, as a redistributive tool, its impact is very limited, as the gain ranges from only 0.2 to 0.7 percent (less than 1 percent) of total expenditure in urban and in rural areas under all three subsidy scenarios. However, subsidies on kerosene would lead to an appreciable impact on the use of firewood: the reduction in firewood use is estimated at 8.6 percent under the 10 percent subsidy case and as high as about 26 percent when the subsidy is 30 percent. At the same time, a subsidy on kerosene would seem to lead only to a modest increase in the demand for fuel. The appropriate level of subsidy would thus depend on the extent of the deforestation problem, the value the society or policymakers attach to the resulting degradation of environment, and availability of alternative tools to address the issue. However, there are limits to the extent the price of kerosene and other petroleum products like diesel can diverge from each other, because they are close substitutes. Too high a subsidy rate would have a large fiscal cost and is likely to lead to an adulteration of regular transport fuels (diesel and petrol). Given these considerations, in the case of Nigeria one can argue that a 10 percent subsidy on kerosene (to address the deforestation externality), with a fiscal cost estimated at 0.1 percent of GDP, may be appropriate. Subsidies on kerosene or cooking fuel (LPG) are also commonplace in many developing countries. While the policy goals are not always clear (or stated explicitly), these subsidies serve to address both the environmental concerns (where relevant) and equity concerns. In advanced countries, notably in Europe, fuel taxes are imposed explicitly to discourage excessive use of motor vehicles, in order to address environmental pollution and urban congestion (noted earlier) problems. ${ }^{17}$ No attempt has been made in this paper to compute such taxes to address urban pollution problems.

${ }^{15}$ These two countries are quite similar with respect to per capita income and population, and follows a similar pattern of firewood and kerosene use; their demand elasticity estimates of these two products are unlikely to be very different.

${ }^{16}$ However, the estimates show that the elasticity of demand of kerosene with respect to the firewood price is positive (small) but statistically insignificant.

${ }^{17}$ Alternatively, some countries (e.g., Singapore) impose limits on the number of vehicles that are allowed in big cities and make use of the price-based auction for allocation. 


\section{E. Estimation of the Benefits of Stable Domestic Prices}

This section examines the desirability of a tax/subsidy scheme as a tool for domestic price stabilization, based on the empirical measures of "arbitrage" and "risk" benefits outlined below. Since producers and consumers are by nature risk averse and the adoption of the border price rule in the face of volatile world prices introduces a great deal of price uncertainty into the domestic market, a case can be made for insulating domestic prices from the volatility of world prices by imposing the taxes or subsidies noted above. ${ }^{18}$ However, detailed information and data are not available to measure the benefits for producers and consumers of price stabilization in petroleum products for Nigeria by following the methodology suggested by Newbery and Stiglitz (1981). Thus simulations with alternative values of the parameters were run to get a feel for the orders of magnitude involved, making use of the modified measure of "arbitrage benefit" and "risk benefit" suggested by Newbery (1990) above.

The benefit estimates defined in equations (1) and (2) and based on alternative parameter values $\left(\varepsilon, \alpha_{\mathrm{p}}{ }^{2}, \alpha\right.$, and $R$ ) are presented in Table 6 (panels A and B). ${ }^{19}$ Since complete stabilization (mean preserving) is likely to be costly and three-fourths of the benefit of complete stabilization is achieved by 50 percent stabilization $(\alpha=0.5)$, we have realistically considered the case of $\alpha=0.5$ only. The results presented in panel $A$ indicate that the arbitrage benefit (Benefit-1: benefit as a proportion of total fuel cost, $B / X)_{A}$ ) varies from 0.7 percent to 5.4 percent of total expenditure on the petroleum products; this level in general rises with the coefficient of variation of price $\left(\alpha_{\mathrm{p}}{ }^{2}\right)$ or the demand elasticity estimates $(\varepsilon)$. In general, the benefit estimates are not high enough to generate sufficient confidence in the stabilization scheme. However, the arbitrage benefit ignores the risk benefit totally, which, as the figures in panel B of Table 6 show, could be considerably higher. These values of $(B / X)_{R}$ (Benefit-1) range widely from 3.4 percent to 20.3 percent of total expenditure on petroleum products under alternative assumptions about the magnitude of $R$ and coefficient of variation of price. On the face of it, the risk benefit looks attractive enough to warrant investigation of the issue, and it does seems that any case of domestic price stabilization will be based largely on the risk benefit. But the optimism wanes somewhat if one looks at the size of the benefit as a proportion of total consumer spending on all commodities and total producer cost $(B / Z)$ and not just the cost of fuel.

Household expenditure surveys in some developing countries show that consumer spending on fuel constitutes about 6-7 percent of the total budget; industrial cost data, however, show

${ }^{18}$ Volatility in domestic prices may also arise from volatility on exchange rate.

${ }^{19}(B / X)=$ benefit as a percent of total expenditure on the commodity;

$\varepsilon=$ elasticity of demand (a constant elasticity demand curve is assumed);

$R=$ coefficient of relative risk aversion; $\alpha=$ fractional reduction in $\alpha_{p}^{2}$ due to stabilization measure; and $\alpha p^{2}=$ coefficient of variation in initial prices. 
Table 6. Arbitrage and Risk Benefits of Partial Price Stabilization

A. Arbitrage Benefit of Partial Price Stabilization (in percent)

\begin{tabular}{ccccc}
\hline $\begin{array}{c}\text { Alternative } \\
\text { Scenarios }\end{array}$ & $\begin{array}{c}\text { Price } \\
\text { Elasticity }\end{array}$ & $100^{*} \mathrm{CV}$ 1/ & $\begin{array}{c}\text { Benefit-1 }(B / X) 2 / \\
\text { (alpha }=0.5)\end{array}$ & $\begin{array}{c}\text { Benefit-2 (B/Z) 3/ } \\
c=0.1\end{array}$ \\
\hline 1 & 0.2 & 9.0 & 0.7 & 0.1 \\
2 & 0.2 & 16.0 & 1.2 & 0.1 \\
3 & 0.2 & 25.0 & 1.9 & 0.2 \\
4 & 0.2 & 36.0 & 2.7 & 0.3 \\
5 & 0.4 & 9.0 & 1.4 & 0.1 \\
6 & 0.4 & 16.0 & 2.4 & 0.2 \\
7 & 0.4 & 25.0 & 3.8 & 0.4 \\
8 & 0.4 & 36.0 & 5.4 & 0.5 \\
\hline
\end{tabular}

B. Risk Benefit of Partial Price Stabilization

\begin{tabular}{ccccc}
\hline $\begin{array}{c}\text { Alternative } \\
\text { Scenarios }\end{array}$ & $\begin{array}{c}\text { Risk } \\
\text { Aversion }\end{array}$ & $100^{*} C V 1 /$ & $\begin{array}{c}\text { Benefit-1 }(B / X) 2 / \\
\text { (alpha }=0.5)\end{array}$ & $\begin{array}{c}\text { Benefit-2 }(B / Z) 3 / \\
c=0.1\end{array}$ \\
\hline 1 & 1.0 & 9.0 & 3.4 & 0.3 \\
2 & 1.0 & 16.0 & 6.0 & 0.6 \\
3 & 1.0 & 25.0 & 9.4 & 0.9 \\
4 & 1.0 & 36.0 & 13.5 & 1.4 \\
5 & 1.5 & 9.0 & 5.1 & 0.5 \\
6 & 1.5 & 16.0 & 9.0 & 0.9 \\
7 & 1.5 & 25.0 & 14.1 & 1.4 \\
8 & 1.5 & 36.0 & 20.3 & 2.0 \\
\hline
\end{tabular}

Source: Author's estimates based on data simulations.

$1 / C V$ stands for coefficient of variation.

$2 /(B / X)$ is a measure of benefit $(B)$ expressed as a proportion of spending on petroleum products $(X)$. Alpha is the fractional reduction in $C V$ due to the stabilization measure.

$3 /(B / Z)$ is a measure of benefit $(B)$ expressed as a proportion of total spending $(Z)$.

$c$ is the share of petroleum products in total spending. 
that fuel cost as a proportion of total variable cost range between 10 percent and 15 percent (Newbery, 1990). For the current exercise, the share of petroleum products in total spending is assumed to be 10 percent $(c=0.1)$. This has the effect of bringing down the size of all benefits to one-tenth of the estimates discussed above (final columns of panels $A$ and $B$ of table 6). When the total arbitrage benefit is added to the risk benefit, the magnitude does not appear to be significant, and, in the scenario case with the highest values of all three parameters, it is still less than 3 percent. Given the complexity of administering such a scheme, the range of estimates of the possible size of the benefit seem to indicate that undertaking the price stabilization through tax and subsidies is not worthwhile (implying that $t_{3}=0$ ).

It is important to note that, even when the potential benefit of a stabilization scheme is large, it may not necessarily justify a price stabilization scheme. There are a number of other measures available to producers and consumers that can in principle mitigate the cost of price instability without resorting to the price stabilization scheme we have been discussing. First, if consumption and cost vary owing to price instability, the effect may be stabilized by lending and borrowing. If there is credit rationing or a constraint operating in the economy, then part of the solution lies in easing the constraint. Second, consumers and producers may already have taken steps to adapt to price instability. Such steps include the reduction of risk through hedging, substituting between fuels, or making technological adaptations. ${ }^{20}$

\section{F. Equity and Revenue Considerations}

On equity grounds, there may be a case for imposing taxes on gasoline and subsidies on kerosene, if the existing tools are not adequate to address the distributional concerns. In developing countries, gasoline is predominantly consumed through motor cars and other vehicles that are owned by the wealthier segment of the population. Thus, in addition to a road user charge, the government may also choose to impose additional taxes on gasoline on grounds of income distribution. The practical limits to such taxes are set by the consideration that the tax should not be so high as to create a very large price differential between gasoline and diesel. Otherwise, people will substitute gasoline for diesel as they are close substitutes. In the current context, for illustrative purpose, we assume the distributional tax $\left(t_{4}\right)$ on gasoline to be 20 percent of the retail border price. This tax which may take the form of excise tax, translates into $\mathrm{N} 7$ per liter for gasoline. ${ }^{21} \mathrm{~W}$ ith regard to kerosene, the estimates

${ }^{20}$ In addition, the existence of a futures market also offers price insurance. It also provides the best estimate of future prices and as such could be useful in guiding investment decisions in the energy sector. But while there are future markets for some oil products, not all fuels are covered and none are covered for more than 12-18 months. It may also be argued that the futures markets are not necessarily preferable to price stabilization for in general they may result in the higher average level of fuel import cost. (Newbery, 1987, p.5); and Newbery and Stiglitz, 1981, Chap. 13, pp. 191-92).

${ }^{21}$ At 20 percent, this level of taxes is lower than the levels of excise taxes on gasoline set in many developing countries. 
presented in Table 5 seem to suggest that a kerosene subsidy is not an effective instrument for redistributing income, as its expenditure share is relatively small and such subsidies may not benefit the poor proportionately more.

In addition, to raise government revenue, it is suggested that the VAT, currently set at 5 percent, be extended to all petroleum products. This translates into a tax $\left(t_{5}\right)$ of N1.8 per liter for gasoline and diesel and N1.7 per liter for kerosene. If the government faces a pressing revenue problem and raising the income tax or general VAT rate is not desirable or feasible, gasoline could be subject to higher taxes (in the form of an excise tax or VAT) as its demand is relatively inelastic and it is consumed by the richest segment of the population. It may be noted that in practice it is often difficult to distinguish between different motives of taxation. For example, as noted above, gasoline is a good candidate for taxation on environmental, distribution, and revenue grounds: its use damages air quality, it is consumed by a wealthier segment of the population, and its demand is relatively inelastic, so that a shift or substitution away from the product is difficult. ${ }^{22}$

\section{G. Results: Illustrative Final Prices of Petroleum Products}

Table 7 summarizes the results of the empirical study and presents illustrative estimates of prices of different petroleum products. It indicates that price of gasoline should be about N56 per liter-much higher than its international border price due to the inclusion of a road user charge, distribution tax, and VAT for revenue reason. Similarly, the price of diesel should be about N49 per liter-much higher than its border price-but the divergence is somewhat smaller than in the case of gasoline, as the fuel is not subject to a distribution tax. However, the price of kerosene should be around N33 per liter, only moderately lower than its international price as it includes a subsidy element to address the deforestation externality and no tax other than the general VAT. Thus, the illustrative exercise also highlights the need for substantial upward adjustments in the prices of petroleum products from their current levels. For gasoline, the required increase is about 115 percent, which would thereby provide additional revenue of about 2.7 percent of GDP; for diesel, the required increase is about 89 percent, with a positive revenue impact of about 0.7 percent of GDP; and, for kerosene, the increase is only about 37 percent, with a positive revenue impact of about 0.2 percent of GDP. The combined revenue impact of the price reform is substantial-3.6 percent of GDP. These estimates, however, are illustrative in nature and the paper does not make specific suggestions for policy reform in Nigeria.

${ }^{22}$ The suggested taxes in the illustrative exercise are all ad valorem taxes (as a proportion of the border price/value of the product), in contrast to specific taxes, often imposed on the products. In practice, specific taxes may be periodically adjusted in response to significant changes in the border price of the products. 
Table 7. Nigeria: Illustrative Estimates of Prices of Petroleum Products, 2002

(Naira per liter, unless otherwise indicated).

\begin{tabular}{|c|c|c|c|}
\hline & $\begin{array}{r}\text { Gasoline } \\
\text { (Petrol) }\end{array}$ & Diesel & Kerosene \\
\hline Retail international (border) price: $\left(p^{*}\right) 1 /$ & 35.2 & 35.4 & 34.6 \\
\hline Estimated Road user charge $(t l)^{2} /$ & 12.0 & 12.0 & 0.0 \\
\hline Environmental tax/subsidy ( $t 2$ ) $3 /$ & $\ldots$ & $\ldots$ & -3.5 \\
\hline Tax/subsidy to reduce variability in price $(t 3)$ & 0.0 & 0.0 & 0.0 \\
\hline Distributional tax (20 percent): ( $t 4$ ) $4 /$ & 7.0 & 0.0 & 0.0 \\
\hline $\operatorname{Tax}(5$ percent VAT) to raise revenue $(t 5) 5 /$ & 1.8 & 1.8 & 1.7 \\
\hline Suggested retail price: $(P)$ & 56.0 & 49.1 & 32.8 \\
\hline \multicolumn{4}{|l|}{ Memorandum items: } \\
\hline Revised price effective from January 2002 & 26.0 & 26.0 & 24.0 \\
\hline Required increase in prices (in percent) & 115.4 & 89.0 & 36.8 \\
\hline Revenue impact of price increase (in billions of naira) & 142.4 & 38.1 & 12.5 \\
\hline Revenue impact of price increase (in percent of GDP) & 2.7 & 0.7 & 0.2 \\
\hline
\end{tabular}

Sources: Nigerian National Petroleum Corporation (NNPC); and author's estimates.

$1 /$ International price estimated in Table 1.

2/ Road user charge estimated in Table 4.

$3 /$ It is suggested that kerosene prices be modestly subsidized ( 10 percent) to address deforestation externality (Table 5).

4/ Tax proposed to address distributional or equity concerns.

5/ It is suggested that the current value-added tax (VAT) be applied to all petroleum products. 


\section{Conclusion}

This paper analyzes how a simple but robust framework derived from the basic principles of public economics can be utilized to set taxes and prices for petroleum products. The key criteria guiding the framework of price setting, including taxes and subsidies, are the following: efficiency, equity, revenue raising, and the correction of externalities in situations where instruments to correct the externalities are limited. Application of the criteria requires a clear separation of consumer (final demand) price and producer (input) price. The paper has provided an operational framework to set the taxes/subsidies in the context of a developing country and made an attempt to estimate different components of petroleum product prices using Nigerian data. The empirical analysis indicates the prices of gasoline (petrol) and diesel should reflect their opportunity costs as measured by the import parity price, as well as a road user charge to recoup the road damage and congestion externality imposed by automobiles. In addition, since gasoline is consumed in motor cars owned predominantly by the richer segment of the population and its demand is relatively inelastic, the tax authorities may also impose taxes on gasoline based on equity and revenue considerations. Kerosene, however, should be mildly subsidized on environmental grounds in developing countries. The limits to kerosene subsidy are set by the price of diesel, which is a close substitute for kerosene. Based on a simulation exercise, the paper does not find a compelling reason to institute a tax or subsidy scheme to stabilize the prices of petroleum products. These conclusions are based on the illustrative exercise and no attempt has been made in the paper to make specific suggestions for policy reform in Nigeria. 


\section{References}

Diamond, P.A., and J. A. Mirrless, 1971, "Optimal Taxation and Public Production: Part I and II," American Economic Review, Vol. 61 (March), pp. 8-27 and Vol. 61 (June), pp. 261-280.

Dixit, A. K., And D. Newbery, 1984, "Setting the Price of Oil in a Distorted Economy," Economic Journal, 1984, (Supplement) pp. 77-82.

Gupta, Sanjeev, and Walter Mahler, 1994, "Taxation of Petroleum Products: Theory and Empirical Evidence," IMF Working Paper 94/32 (Washington: International Monetary Fund).

Gupta, Sanjeev, and others, 2002, "Issues in Domestic Petroleum Pricing in Oil-Producing Countries," IMF Working Paper 02/140 (Washington: International Monetary Fund).

Hossain, Shahabuddin M, 1991, "Demand Patterns of Energy Products in BangladeshEvidence from Household Survey Data" (unpublished; Cambridge: Cambridge University).

—_. 1995, "The Equity Impact of Value Added Tax," IMF Staff Papers, Vol. 42 (June), pp. 411-30.

Hughes, G.A., 1983, The Impact of Fuel Prices in Thailand (Washington: World Bank).

Metschies, Gerhard, P., 2001, Fuel Prices and Vehicle Taxation, $2^{\text {nd }}$ ed. (Eschborn, Germany: Deutsche Gesselschaft für Technische Zusammenarbeit (GTZ)).

Newbery, David M., 1985, "Efficiency and Equity Criteria in Energy Pricing with Practical Applications to LDCs in Asia," in Criteria for Energy Pricing Policy, ed. by Corazon Siddayao (London: Graham \& Trotman), pp. 65-88.

— 1987, "Pricing Policy," Department of Applied Economics, Economics Reprint No. 125, (Cambridge: University of Cambridge).

—_ 1988, "Charging for Roads," World Bank Research Observer, Vol. 3 (July), pp.119-38.

— 1990, "Growth Externalities and Taxation," Department of Applied Economics Working Paper (Cambridge: Cambridge University).

— , and Joseph E. Stiglitz, 1981, The Theory of Commodity Price Stabilization: A Study in the Economics of Risk (Oxford: Clarendon Press).

World Bank, 1988, "Road Transport Taxation in Developing Countries: The Design of User Charges and Taxes for Tunisia," World Bank Discussion Paper No. 26 (Washington: World Bank). 